\title{
The Terrorism of 'Counterterrorism': The Use and Abuse of Anti-Terrorism Law, the Case of Ethiopia
}

\author{
Zelalem Kibret, (LL.B, LL.M) \\ Scholar-in-Residence at the Center for Human Rights and Global Justice, \\ New York University, School of Law
}

doi: 10.19044/esj.2017.v13n13p504 URL: http://dx.doi.org/10.19044/esj.2017.v13n13p504

\begin{abstract}
Since its enactment on July 2009, Ethiopia's anti-terrorism proclamation is at the very center of almost every political discourse in the nation. Many dissidents fall into its trap and by day its effect is becoming more far-reaching and resonating. The widely written provisions of the law make it susceptible to misapplication and prone to abuse. Whilst the state is staunchly firing back to the detractors of the law and its mis(application) alike, however, simultaneously it doubled down utilizing it, by every new day. This paper, after examining one hundred twenty three terrorism charges pressed against nearly one thousand individuals - in a sixty-six months period of time-concludes that: Ethiopia's anti-terrorism law is a colossal failure for counterterrorism, which only exemplifies how not to counter terrorism.
\end{abstract}

Keywords: Anti-terrorism law, Counterterrorism, Dissidents, Ethiopia, Terrorism, War on terror

\section{Introduction}

'Terrorism' and 'the global war on terror', alias Overseas Contingency Operations-defined and crafted the zeitgeist of the first two decades of the $21^{\text {st }}$ century. Terrorism is becoming a must-have ingredient of foreign policy, criminal justice administrations, and daily news storiesaround the globe. Especially, since after the September 11, 2001, terrorist attack on one of the most powerful nations in the world, the United States of America, every aspect of interstate as well intrastate relations changed-in a way that mainly guided by the narrative of terrorism, an act which lacks a universally-agreed comprehensive definition, but demonstrates hostility and evil motives. In other words, the $21^{\text {st }}$ century is "the age of [t]errorism" .

\footnotetext{
${ }^{1}$ Anthony Nocella and Steve Best (2004), Terrorists or Freedom Fighters? Reflections on the Liberation of Animals.
} 
Terrorism redefined foreign policies, geopolitical interests, and security concerns. Currently, it is seldom to find a state which had not devised a counterterrorism strategy - whether in a Criminal Justice Model or the Intelligence Model or the War Model. Boots are deployed in many parts of the world to hunt terrorists; tens of thousands are locked in jail-hence states can stop terrorists from 'disrupting the public order' - and billions of dollars are invested every year in security projects.

Nevertheless, in spite of that terrorism is becoming a household name, defining and explaining it is/was appeared to be a daunting task. Long before the post-2001 global 'war on terror' was waged, terrorism was already recognized as 'a fad word' 2 . In 1980, in answering the question of 'What is Terrorism?', Brian Jenkins aptly pointed how our perspective affects our understanding of it as "[t]hus seems to depend on one's point of view. Use of the term [terrorism] implies a moral judgment; and if one party can successfully attach the label terrorist to its opponent, then it has indirectly persuaded others to adopt its moral view point". This pejorative ${ }^{3}$ understanding of the term makes the scholarly as well as the political effort of defining it almost impossible. Minding this 'definitional vacuum' ${ }^{4}$ the International community - led by the United Nations (hereinafter the UN) delegates the power of defining terrorism to member states through their domestic laws.

Ethiopia was among one of the member states who took this delegated chance to mount on the fast-wheeling 'war on terror' bandwagon. After many years of deliberation ${ }^{5}$ and numerous critical reports from different entities, Ethiopia finally adopts its Anti-terrorism Proclamation (hereinafter the ATP) on uly 2009. In spite of the fierce resistance from different domestic and international bodies that the law is sweeping in nature and draconian ${ }^{6}$, the Ethiopian government justifies the enactment of the bill

\footnotetext{
${ }^{2}$ Brian Michael Jenkins (1980), The Study Of Terrorism: Definitional Problems, The Rand Corporation.

${ }^{3}$ Bruce Hoffman (2006), Inside Terrorism, Colombia University

${ }^{4}$ Scholars of numerous disciplines uses different phrases that are indicative of the difficulty in defining terrorism inter alia, 'definitional impasse', 'definitional failure', 'definitional vacuum', 'semantic chaos', 'semantic swamp', and etcetera are used by various experts of terrorism. For more on this see, Grozdanova, R. (2014), Terrorism' - Too Elusive a Term for an International Legal Definition? Netherlands International Law Review, 61(3), 305334.

${ }^{5}$ See Country Reports on Human Rights, US State department, Bureau of Democracy, Human Rights and Labor for the year 2004, 2006 and 2007, available at https://www.state.gov/j/drl/rls/hrrpt/

6 Among others, see Human Rights Watch (2009), Analysis of Ethiopia's Draft AntiTerrorism Law, Article 19 (2009), Comment on Anti-Terrorism Proclamation, Committee to Protect Journalists (2009), Anti-terrorism legislation further restricts Ethiopian press, and
} 
as an essential counterterrorism tool ${ }^{7}$. By proscribing three Ethiopian political insurgent groups-Oromo Liberation Front (hereinafter OLF), Ogaden National Liberation Front (hereinafter ONLF), and Ginbot 7 for Justice, Freedom and Democracy (hereinafter Ginbot 7) along with two international terrorist groups-Al-Qaeda and Al-Shabaab-on June 2011, the state took the longest leap to implement the ATP. Since then, the victims/targets - perspective wise relatively different adjectives used by different entities — of the ATP are snowballing and that eventually makes the applicability of the law vague at its best and preposterous at worst.

Beyond merely witnessing the mis(application) of the law, there are several reasons that motivate the author of this paper to explore the applicability of the ATP. The first and the foremost one is, sheer nonexistence of academic works with regard to the implementation of the law. Although there are some works done discussing the constitutionality of the ATP, its sweeping approach of painting dissent in a broad brush, and how it ill-defined terrorism and potentially causing abuse ${ }^{8}$, however, so far, there is no academic study answering the question of how the ATP was/is implemented-aimed at weigh the vindication or disapproval of its the proponents or critics respectively. Hence, this work takes a new approach by studying Ethiopia's anti-terrorism law from the practical point of view. For that end, the author studied one hundred twenty three separate court cases, which constitute nine hundred eighty five individuals/legal persons in the sixty six months period-stretched from September, 2011 to March 2017and tries to shade a light on the law, its application as well as its implication on the future of dissent and counterterrorism in Ethiopia.

Secondly, the fact that author of this work himself was once a victim of ATP, gives him a chance to closely look and monitor the implementation of it and urges to do this research. For that matter, the data collection for this research was started while the author was in prison.

\footnotetext{
Amnesty International (2009), Ethiopia: New Anti-Terrorism Proclamation Jeopardizes Freedom Of Expression.

${ }^{7}$ Minutes of the public discussion on the draft of Ethiopia's Antiterrorism law (June 2009) as quoted by Hiruy Wube "Some Points on the Ethiopian Anti-terrorism Law from Human Rights Perspective” Journal of Ethiopian Law, Vol, 25 No.2, pp.43-46

${ }^{8}$ See Peter Sekyere and Bossman Asare, An Examination Of Ethiopia's Anti -Terrorism Proclamation On Fundamental Human Rights (2016), Dersolegn Yeneabt Mekonen, Assessing Controversial Issues of the Ethiopian Anti-Terrorism Law: A Special Focus on Substantive Matters (2015),Hiruy Wubie, Some Points on the Ethiopian Anti-Terrorism Law from Human Rights Perspective (2012), Wondwossen Demissie Kassa, The Scope of Definition of a Terrorist Act under Ethiopian Law: Appraisal of its Compatibility with Regional and International Counterterrorism Instruments (2014), Asmelash Yohannes Teklu, Enhancing Human Rights Protection and National Security by Proscribing a 'Terrorist' Organisation: the Ethiopian Dilemma (2016), and etcetera.
} 
Thirdly and most importantly, the ever-heating and fierce debate on the use and abuse the ATP in Ethiopia motivates the author to delve the debate deep and shade a light on the story. The current ruling elite in Ethiopia justifies the necessity of the law — since its early age of drafting —as a western adapted important counterterrorism tool. Contrarily, detractors of the law posit a critical view of it-by analyzing the substantive and procedural components of the proclamation—as a legal monster which was cunningly crafted to curtail political dissent and to gag opposing voices.

Cognizant of the academic loophole, along with aforementioned rationales, the author exerts his effort to weigh the implementation of the ATP since its enactment and tries to pinpoint the flaws implicated.

\section{Let States fill the 'Definitional Vacuum'9}

Terrorism is neither a recent phenomenon nor an act that surrenders for 'the tyranny of geography'. Although, its ubiquity and universal nature makes it seem easy to grasp, nonetheless, defining terrorism-especially defining it for legal purposes-has never been an easy task and it continued to be painstaking. Inter alia, this basically resulted from the pejorative assertion of the term itself. The Political Philosopher Tomis Kaptian rightly observed the danger of the 'terrorist' label and its pejorative tone:

Because of its negative connotation, the "terrorist" label discredits any individuals or groups to which it is affixed. It dehumanizes them, places them outside the norms of acceptable social and political behavior, and portrays them as people who cannot be reasoned with. ${ }^{10}$

This takes us to the conclusion that because of its entire negative connotational semantic assertion, defining terrorism in a comprehensive manner is a task that seems never yield a result. That is why some scholars takes this unending battle to the extent of suggesting to leave the 'semantic chaos ${ }^{11}$ alone and deal with the threat itself. In beating this drum, two decades ago, Rosalyn Higgins, a judge to the International Court of Justiceenunciated that "[t]errorism [a]s a term without any legal significance. It is merely a convenient way of alluding to activities, whether of States or of individuals, widely disapproved of and in which either the methods used are unlawful, or the targets protected, or both" ${ }^{12}$.

Unless there is an agreeable stance over it-at least to a certain extent-however, dealing with the threat is an impossible mission. After all,

\footnotetext{
${ }^{9}$ See Supra 4

${ }^{10}$ Tomis Kaptian, Can Terrorism be Justified? in Richard Fumerton and Diane Jeske, eds. Readings in Political Philosophy (Broadview Press, 2011), 1068-1087

${ }^{11}$ See Supra 1

12 Rosalyn Higgins, ‘The General International Law of Terrorism' in Rosalyn Higgins and Maurice Flory (eds), Terrorism and International Law (1997) 14, 28.
} 
the fight against terrorism begins with identifying who is a terrorist and who is not ${ }^{13}$.

The quarrel over defining terrorism does not confine itself in the academic and legal arena, rather it transcends to States as well as the International political and diplomatic arena. Globally, roughly for the last fifty years-since the first United Nations convention on terrorism adopted in $1963^{14}$ - the UN was/is embattling over an all agreed definition of terrorism, in which it was not able to leap beyond specific working definitions adopted on sporadic and piecemeal legal instruments. Consequently, the international body refrained-until now-from adopting a comprehensive and mandatory definition of terrorism. ${ }^{15}$ Hence, in spite of the plethora of International legal instruments on terrorism, we lacked an inclusive and workable definition of it on the one hand, and a common understanding of the act itself on the other hand. This results multitude ${ }^{16}$ of academic and legal definitions proposed and asserted by different actorsincluding individuals, states, International bodies, and so forth.

Among others, Sir Jeremy Greenstock, the former British Ambassador to the UN simplistically suggests a circular definition of terrorism as, “[W]hat looks, smells, and kills like terrorism, is terrorism”.

\footnotetext{
${ }^{13}$ Alex Schmid in his work Terrorism - The Definitional Problem summed this definitional squabble as "Brian Jenkins (RAND Corporation), one of the first researchers in the field of terrorism, has called the definition problem the "Bermuda Triangle of terrorism." The late Bowyer Bell (MIT), in turn, held "tell me what you think about terrorism, and I tell you who you are. Philip Schlesinger, a British sociologist, even argued "....that no commonly agreed definition can in principle be reached, because the very process of definition is in itself part of a wider contestation over ideologies or political objectives.”

${ }^{14}$ Ben Saul (2006) on The Legal Response of the League of Nations to Terrorism published at the Journal of International Criminal Justice discussed the status of terrorism during the era of League of Nations in further details.

15 Nothing testifies the challenge of defining terrorism as the United Nations Model Legislative Provisions against Terrorism adopted on February 2009. The Model provisions are meant to be suggesting states-without imposing on them-a comprehensive definition of terrorism and related activities. Nonetheless, the Model proposed six different definitions of a 'terrorist act' and let/recommend states to pick their own preferred definition. Disclaiming the nature of its proposed definition, the proposal underlines that "States are reminded that they ARE NOT BOUND by any UN instrument to define 'terrorist acts'. [...] Accordingly, [States] can change, expand or restrict the proposed definitions in accordance with their specific needs, or taking into account alternative definitions. In departing from the proposed formulation, however, particular attention should be given to ensuring that chosen language is sufficiently precise and unambiguous to suit criminal law drafting requirements."

${ }^{16}$ In 1988 Alex Schmid, Albert Jongman, et al., studied working definitions of terrorism and published Political Terrorism: A New Guide to Actors, Authors, Concepts, Data Bases, Theories, and Literature, in which they identified 109 different definition suggested by 200 different terrorism experts.
} 
Likewise, Louise Richardson pointed that, "like pornography, we know terrorism when we see it" ${ }^{17}$. Diverging from these circular assertions, Richard Rubenstein in his part remarked "[a] definition of terrorism is hopeless [. . .][because] terrorism is just violence that you don't like." ${ }^{18}$ Still scholars like John Whitbeck stress on the subjectivity of defining terrorism in which he argues, "[p]erhaps the only honest and globally workable definition of terrorism is an explicitly subjective one - violence I don't support." ${ }^{19}$ We can continue referring to numerous definitions and arguments, the list is bottomless. But, the multitude of understanding and assertion only suggests the mayhem of defining terrorism we are all in.

Cognizant of the definitional impasse, the United Nations-as a multistate organ-urges and let states to domesticate terrorism and defined it in their domestic laws. That is why states mainly_and unusually — adapt their anti-terrorism laws from other states than adopting from international legal instruments.

Letting states to define terrorism based on their own understanding and reality is a two-edged sword solution. On the one edge, it resolve the definitional impasse that the international community stuck with for long, but still struggling to come up with an all agreed and all-inclusive definition, on the one hand, however, on the other edge, states full autonomy in defining this politically loaded act makes the act/concept prone to abuses. To paraphrase this contradictory implication, each state can define terrorism in its own term and motive but, that could result un(intended) consequences.

\section{'Outsourcing Guantánamo’: an opportunity to Ethiopia}

Late 2006, Ethiopia declares a preemptive 'self-defense' war against its neighbor Somalia. Triggered by a war propaganda disseminated by the Islamic Courts Union (IUC),a loose Union of Sharia Courts in Somalia that was established paralleling the Transitional Federal Government of Somalia $^{20}$ —outside of the capital Mogadishu. By the time, Ethiopia justifies its declaration as a measure taken as per Article 51 of the UN Charter, which allows defending itself from the war mongering jihadists in Mogadishu. The anticipatory 'self-defense' measure was fiercely criticized at home and

\footnotetext{
${ }^{17}$ Louise Richardson (2007), What Terrorists Want: Understanding the Enemy, Containing the Threat

${ }^{18}$ Richard Rubenstein (1989) cited Supra 17.

${ }^{19}$ John V. Whitbeck (2001), 'Terrorism': The word itself is dangerous, The Daily Star

${ }^{20}$ Cedric Barnes and Harun Hassan , The Rise and Fall of Mogadishu's Islamic Courts, Journal of Eastern African Studies, Vol. 1, No. 2 (2007), pp. 151-160.
} 
abroad, nonetheless $^{21}$. In spite of the resistance, Ethiopia went to Somalia, ousts IUC, but scored a little far-reaching effect. ${ }^{22}$ However, one thing the Somalia misadventure pronounces was that Ethiopia's wish to fore stand and allied with the West's Global War on Terror (hereinafter the GWT).

Following Ethiopia's Somalia invasion ${ }^{23}$, a story of 'terrorist' rendition, which majorly involves Ethiopia-from different horn of African countries-broke out ${ }^{24}$. This new development later acknowledged Ethiopia and publicly announces the detention of forty-one individuals from seventeen different countries. ${ }^{25}$ Consequent to deploying soldiers in Somalia the rendition story was an addition and explicit indication of the Ethiopian government's intention in riding on GWT bandwagon. Human Rights organizations - who followed this unprecedented phenomenon in the hornwere critical of transporting individuals from another country to Ethiopia, which was/is known for its ill treatment of prisoners. Among many, John Sifton, Human Rights Watch expert on counterterrorism describes the rendition phenomenon as "decentralized, outsourced Guantanamo"26, in which Ethiopia, act as a site and host of the rendition. This early case of the Ethiopian states' involvement in interrogating and prosecuting alleged terrorists, paves the way wide for it to using the criminal justice system as a counterterrorism tool ${ }^{27}$

Although, Ethiopia's 'action' against Somalia-whether it is an invasion or self-defense-was a millstone on the fight against terrorism, however, prior to 2006, Ethiopia was expressing in many circumstances, its

${ }^{21}$ At home, members of the then Ethiopian parliament were fiercely pronounced their objection to moving to Somalia and many International bodies were warning against the 'reckless' and 'exit-less' intervention strategy.

${ }^{22}$ Christopher Daniels (2012), Somali Piracy and Terrorism in the Horn of Africa (A Scarecrow Press Series)

${ }^{23}$ Opponents of this move often used the term 'invasion', however the Ethiopian government prefers to call it a 'preemptive self-defense' taken as per Article 51 of the UN Charter, which mandated states to defend themselves from any kind of 'clear and present danger' that probably endanger the nations' wellbeing.

${ }^{24}$ See, Salim Lone, Inside Africa's Guantánamo, The Guardian (April 27, 2007) Robert Walker, Investigating 'Africa's Guantanamo', The BBC (October 01, 2008)

${ }^{25}$ The New York Times, Ethiopia concedes it is holding 41 terror suspects, (April 10, 2007)

${ }^{26}$ US interrogating at Africa's secret prisons (April 07, 2007), NBC News, available at, http://www.nbcnews.com/id/17935971/ns/world_news-africa/t/ap-us-interrogating-africassecret-prisons/\#.WMBlbG_yvcs

${ }^{27}$ Among some of prominent terrorism trials-prior to 2009-the trial of Bashir Makhtal, Ethiopian born Canadian is worth to be mentioned here. Bashir was a businessman who was working in the horn of Africa. In one fateful day, in 2006, he found himself in crossfire and renditioned to Ethiopia by the Kenyan authorities, alleged of contacting with operatives within the Ogaden National Liberation Front (ONLF). As a result, he was convicted of terrorism and sentenced to life imprisonment. Despite the global condemnation and Canadian government's call for his release, Bashir is still in Ethiopian prison. 
keen interest and determination to join the global effort of quelling terrorism. Justifying that its interest, the government of Ethiopia oftentimes assert that prior to 9/11 Ethiopia was fighting terrorism 'alone' in different fronts. ${ }^{28} \mathrm{At}$ this juncture, a bombing incident in Addis Ababa - on the first year anniversary of $9 / 11$ attack, September 11, 2002, for example, is a case worthy mention. On September 11, 2002 evening a bomb blasted in a small hotel at the heart of Addis Ababa, the capital of Ethiopia. ${ }^{29}$ The Ethiopian government immediately blames the Oromo Liberation Front (hereinafter the OLF) - an old rebel group which fought against the previous military regimes in Ethiopia along with the incumbent, Ethiopian People Revolutionary Democratic Front (hereinafter the EPRDF)—as the perpetrator of the action and called the attack 'a terrorist act'. However, the OLF later denounces the allegation in a damning statement, pointing to the motive behind as, "[o]ur [o]rganization considers terrorism in all its forms as an act of desperation [...] the regime in Addis Ababa was desperately trying to jump on the anti-terrorism bandwagon to use it as a political ticket to stay in power, to deceive the international community and blackmail opposition forces" ${ }^{30}$. Since then, the September 11, 2002 incident becomes one of the state's justifications in introducing an anti-terrorism law.

Summing up, headlines like 'Ethiopia remains tough on terrorism', ${ }^{31}$, 'Ethiopia takes military action against multi-national terrorism groups, ${ }^{32}$, 'Suspected terrorists on trial in Ethiopia' ${ }^{33}$, and so forth, precedes 9/11 as well Ethiopia's 2006 Somalia mishap. The post-9/11 world only galvanized the Ethiopian government's effort in making terrorism at the center of its foreign and security policy.

Drifting from such major historical underpinnings, the model the state used to employ in the pre-2009 era was, 'the war model' of counterterrorism - a model that advocates for waging a full scale war on

\footnotetext{
${ }^{28}$ Oftentimes, the Ethiopian government made an inflated account on the nature and the number of 'terrorist attacks' prior to 2009. The former Deputy Director of the Ethiopian National Intelligence Security Service, Woldeselassie Woldemichael in his book, Terrorism in Ethiopia and the Horn of Africa threat, impact and response (2010) claimed two hundred thirty eight 'terrorist attacks' from 1991 to 2009. Brihanu Adelo, one of the drafter of the antiterrorism law, on the other hand, claims a far less numbers of 'terrorist attacks', which he tallied only sixty five terrorist attacks' in the same period of time.

${ }^{29}$ Nita Bhalla (02 October, 2002), Ethiopia links blast to Oromo rebels, available at http://news.bbc.co.uk/2/hi/africa/2293185.stm

30 The Oromo Liberation Front (September 18, 2002), Press Statement.

31 "Ethiopia remains tough on terrorism", Ethiopia Observer, September, 1996, Volume 05, Issue 07.

${ }^{32}$ Ibid.

33 "Suspected terrorists on trial in Ethiopia", Ethiopia Observer, April 1996, Volume 05, Issue, 03.
} 
terrorists - and somehow 'the intelligence model'-a model that advocates for surveilling terrorists and gathering intelligence reports on their activities $^{34}$. These models were mainly targeting foreigners in foreign soillike the case of Somalia-and in a certain way proved to be effective. In the pre-2009 era of countering terrorism, notwithstanding that there were some attempts to brought terrorists to justice, the criminal justice model of counter terrorism was barley used. In the rare circumstances that terrorists were brought to justice, the regular criminal justice mechanism and the customary justice apparatuses were enforced ${ }^{35}$.

Generally, the changed global rhetoric on terrorism after the 9/11 terrorist attack opened the door wide to Ethiopia to mount over the counterterrorism bandwagon, which eventually paves the way for adopting its own anti-terrorism law, on July 2009-which as it later provedsignificantly impacted the political and legal sphere of the nation.

\section{The nuts and bolts of Proclamation No. 652/2009}

"Today is a historic day. All of us in this house-sitting left and right-should resist this law. If not, from this now onwards we are surrendering our country's fate to be determined by dictators, thugs, and the police." 36

This was the prophetic warning by one of Ethiopia's prominent parliamentarian, Bulcha Demeksa, moments before Ethiopia’s Anti-terrorism proclamation Number 652/2009 passed, on July 07, 2009. For Bulcha and many critics of the law, it curtails individuals' substantive rights by widely defining terrorism and conflating dissent with terrorism; as well it erodes procedural constitutional rights by widening the power of the state security apparatus - the police, the intelligence and the prosecutor general. ${ }^{37}$

A detailed legal analysis of the ATP is beyond the scope of this paper and it is done elsewhere ${ }^{38}$. However, in a belief that shading a light on the background and the basic pillars of the law is essential to understand its

\footnotetext{
${ }^{34}$ See Supra 29.

${ }^{35}$ See, for example, Safwat Hassan Abdel-Ghani et al $v$ the Federal Public Prosecutor case (1995) and Muhamed Mahemmed Farahet al v the Federal Public Prosecutor case (1998), in which alleged terrorists attempted to assassinate the former president of Egypt, Hosni Mubarak and former Ethiopia's UN representative, Dr. Abdul Mejid Hussien, respectively. In both cases the court convicts the alleged assassins as per the regular Penal Code and procedural rules.

${ }^{36}$ A translation of his Amharic speech in the parliament:

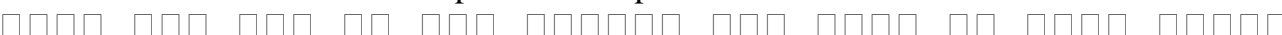

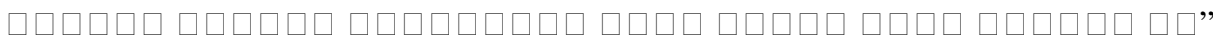

${ }^{37}$ See Supra 6

${ }^{38}$ See Supra 8
} 
application, the author will tries to discuss the basic tenets of the proclamation.

As tried to indicate above, Ethiopia’s move to enacting a separate law governing terrorism and related activities was an issue in the table before its actual adoption on July 2009. Since the year 2001, Ethiopia reached to different stakeholders in search of a model anti-terrorism law and discussed the importance of having one. However, in the 2002-detouring from its stand, Ethiopia was assuring the UN about the adequacy of the regular criminal justice materials and apparatus in countering terrorism ${ }^{39}$. Flipping from this expressed position, in the year $2004^{40}, 2006^{41}$, and $2007^{42}$, a bill on criminalizing terrorism and persecuting terrorists was tabled to the House of People's Representative (hereinafter HPR). In all the time it was tabled, it failed to pass to the final stage of adoption for unclear reasons, nonetheless. In the meantime, being a member of the UN, Ethiopia adopts half of the UN legal instruments concerning terrorism and related activities ${ }^{43}$. Besides this various UN Security Council resolutions ${ }^{44}$ are also mandatorily applicable in Ethiopia.

\footnotetext{
${ }^{39}$ Abdulmejid Hussein (Ambassador), Ethiopia's Permanent Representative to the UN (2002), Letter dated 7 November 2002 from the Chairman of the Security Council Committee established pursuant to resolution 1373 (2001) concerning counter-terrorism addressed to the President of the Security Council, November, 2002.

${ }^{40}$ US State Department, Country Reports on Terrorism Office Of The Coordinator For Counterterrorism (2005), available at, https://www.state.gov/j/ct/rls/crt/45388.htm

${ }^{41}$ US State Department, Country Reports on Terrorism Office Of The Coordinator For Counterterrorism (2007), available at https://www.state.gov/j/ct/rls/crt/2006/82730.htm

${ }^{42}$ US State Department, Country Reports on Terrorism Office Of The Coordinator For Counterterrorism (2008), available at https://www.state.gov/j/ct/rls/crt/2007/103705.htm

${ }^{43}$ Since the first comprehensive convention on terrorism, the Convention on Offences and Certain Other Acts Committed On board Aircraft was adopted in 1963 until the time this paper was written, the UN proposed a total of nineteen Universal antiterrorism legal instruments for states to ratify. Ethiopia as a founding member of the UN is a signatory of nine of these instruments namely; Convention on Offences and Certain Other Acts Committed On Board Aircraft (Ratified on March 27, 1979), Convention for the Suppression of Unlawful Acts against the Safety of Civil Aviation (Ratified on September 23, 1971), Convention for the Suppression of Unlawful Seizure of Aircraft (Ratified on December 22, 1993), Protocol For The Suppression Of Unlawful Acts Of Violence At Airports Serving International Civil Aviation (Ratified on December 15, 1999), Convention on the Prevention and Punishment of Crimes against Internationally Protected Persons, including Diplomatic Agents (Ratified on April 16, 2003), International Convention against the Taking of Hostages (Ratifies on April 16, 2003), International Convention for the Suppression of Terrorist Bombings (Ratified on April 16, 2003), International Convention for the Suppression of the Financing of Terrorism (Ratified on March 20, 2012), and Convention for the Suppression of Unlawful Acts against the Safety of Maritime Navigation (Ratified on July 29, 2013).

${ }^{44}$ Among other resolutions see, U.N. Security Council, 3915th Meeting, Resolution 1189 (1998) [Condemning International terrorism]. (S/RES/1189), U.N. Security Council, 4053rd
} 
Finally, after years of failed attempts, on January 2009, the government of Ethiopia circulates the draft of the anti-terrorism law among confidants, internally. The draft was leaked to International Human Rights Organizations and many of them expressed their concern over the over broadly designed law. ${ }^{45}$ By the time, officials were expressing their dismay over the leaked copy of the law and that was one of the definite reasons for many to be concerned-the fact that the state is trying to legislate a new law without the public's participation in secret was an indicative of the motive behind the proposed law. Later, after an insignificant discussion in the state house, the draft was adopted as Proclamation on Anti-terrorism No. 652/2009, with little insignificant changes.

Reading the preamble of the proclamation cumulatively with the expressed motives of the drafters during the pre-enactment discussions, told us, basically inter alia, there were three major reasons ${ }^{46}$ that necessitates the adoption of the anti-terrorism law-the legal loophole on governing terrorism and related activities, executing Ethiopia's international commitments to counterterrorism, and enabling the existing security apparatus to counterterrorism.

Notwithstanding that a theoretical and legal analysis of the ATP is far afield of this work, but, a limited discussion on the major/controversial provisions of it will clear the cloud of misunderstanding on its applicability. The ATP mainly raises rabble on two core notions, an overbroad substantive conception of terrorism and an overblown executive power camouflaged as enabling legal procedures.

\footnotetext{
Meeting, Resolution 1269 (1999) [on the responsibility of the Security Council in the maintenance of international peace and security], (S/RES/1269) resolution, U.N. Security Council, 43705th Meeting, Resolution 1368 (2001) [Threats to international peace and security caused by terrorist acts]. (S/RES/1368), U.N. Security Council, 4385th Meeting, Resolution 1373 (2001) [Threats to international peace and security caused by terrorist acts], and U.N. Security Council, 5053rd Meeting, Resolution 1566 (2004) [Threats to international peace and security caused by terrorist acts]. (S/RES/1566)

${ }^{45}$ See Supra 6.

${ }^{46}$ As one of the drafters of the antiterrorism law, Dr. Hashim Tewfik remarks the triggering factors that necessitates the law are "[a]bsence of a clear provision criminalizing acts of terrorism as such, inadequate penalties incompatible with the heinous nature of the crimes, failure to criminalize an act of bombing a place of public use, a state or government facility, a public transportation system or an infrastructure facility, failure to criminalize acts of threat to kill or injure a hostage in order to compel a third party to do or abstain from doing any act, failure to criminalize financing a terrorist act as a separate crime, failure to criminalize acts of nuclear terrorism and acts committed with the purpose of coercing a government or a group to abstain from having a particular stand point are among the serious limitations of the Criminal Code" Cited by Hiruye Wube, Some Points on the Ethiopian Anti-Terrorism Law from Human Rights Perspective (2012).
} 


\section{Contentious substance}

Mindful of that the road to defining terrorism is tumultuous, the ATP avoids defining terrorism directly. Rather it defines 'terrorist acts' and terrorist organizations' and declares anyone who has a smidgen of connection with the listed acts and proscribed organizations-as it will be discussed later — as a terrorist. Quoting directly from the law, "[w]hosoever or a group intending to advance a political, religious or ideological cause by coercing the government, intimidating the public or section of the public, or destabilizing or destroying the fundamental political, constitutional or, economic or social institutions of the country [-] causes a person's death or serious bodily injury; creates serious risk to the safety or health of the public or section of the public; commits kidnapping or hostage taking; causes serious damage to property; causes damage to natural resource, environment, historical or cultural heritages; and endangers, seizes or puts under control, causes serious interference or disruption of any public service" $^{47}$ is defined as a terrorist under the ATP. Moreover, any act of planning, preparation, conspiracy, incitement, and attempt of the aforementioned acts also is provided as a reason to incriminate individuals/organizations as a terrorist. ${ }^{48}$

The debate over the substance of the ATP starts from this derivative definition of terrorism as prescribed by it. Those who criticize the law oftentimes mentioned the overbroad and sweeping nature of the definition. One of the earliest critics of the law pointed that "[t]he [...] Proclamation provides an extremely broad and ambiguous definition of terrorism that could be used to criminalize non-violent political dissent and various other activities that should not be deemed as terrorism." ${ }^{49}$ This 'overly broad definition' criticism of the law was reiterated by different scholars and organizations alike. ${ }^{50}$ Nonetheless, the state always sailed the ship to the other direction. The state's defense of this broadly written definition was chiefly calling a straw man, which is evasive from the substance of the criticism. By arguing as the law is a carbon copy from the USA PATRIOT ${ }^{51}$

\footnotetext{
${ }^{47}$ Article 3, A proclamation Anti-terrorism No. 652/2009

${ }^{48}$ Id Article 4

${ }^{49}$ Human Rights Watch, Analysis of Ethiopia's Draft Anti-Terrorism Proclamation, March 9, 2009, p. 3.

50 See Wondwossen Demissie Kassa, The Scope of Definition of a Terrorist Act under Ethiopian Law: Appraisal of its Compatibility with Regional and International Counterterrorism Instruments (2014), Hiruye Wube, Some Points on the Ethiopian AntiTerrorism Law from Human Rights Perspective (2012)

${ }^{51}$ Uniting and Strengthening America by Providing Appropriate Tools Required to Intercept and Obstruct Terrorism (USA PATRIOT Act) Act, H. R. 3162, 107th Cong. (2001)
} 
act 2001-which was replaced by the USA FREEDOM ${ }^{52}$ act in 2015-the British Terrorism act 2000 — which was amended at least four times ${ }^{53}$ - the European Union Model anti-terrorism law, and the Australian anti-terrorism Bills, ${ }^{54}$ the government justifies the enactment of the law as it is. However, beyond referencing other countries laws as a justification, the state is not-so far-come up with any plausible defense against its detractors who are well remarking the overly written definition, which makes the law prone for abuse.

Bouncing from this condemnation, the other major rebuke forwarded against the substantive essence of the law is its criminalization of the broadly listed acts like, rendering support to terrorism-knowingly or unknowingly ${ }^{55}$ — publications that rendered support to groups designated as terrorists-knowingly or unknowingly ${ }^{56}$-individuals who knowingly and unknowingly omits to cooperation with the state in its effort of countering terrorism $^{57}$, and other unqualified and vaguely provided acts. Furthermore, the ATP, without distinguishing domestic terrorism with International terrorism, provides rules of proscription and de-proscription of terrorist organizations in Ethiopia. This, as it later in this paper discussed in depth, wreaks havoc on the whole legal and political landscape in Ethiopia.

Additionally, the law stipulates overextended executive powers to the police $^{58}$, the intelligence ${ }^{59}$ and the public prosecutor ${ }^{60}$ is also a further criticism on the substance of the ATP, which eventually, puts the proclamation at the center of controversy and made it political cause.

\section{Procedural hurdles}

As the previous discussion indicates, one of pushing factors behind the enactment of the ATP was the need for enabling the state security apparatus to effectively investigate, prosecute, and counter terrorism. ${ }^{61}$ Accordingly, the ATP, in a deviant of the regular criminal justice

\footnotetext{
${ }^{52}$ Uniting And Strengthening America By Fulfilling Rights And Ensuring Effective Discipline Over Monitoring Act (USA FREEDOM Act) Act, H. R. 114-23, 115th Cong. (2015)

${ }^{53}$ The UK Terrorism Act 2000 (c.11) was amended four times in 2005, 2006, 2008, and 2015.

${ }^{54}$ Parliament and public discussions prior to-and after-the adoption of the antiterrorism law.

${ }^{55}$ Article 5, A proclamation Anti-terrorism No. 652/2009

${ }^{56} I d$, Article 6

${ }^{57}$ Id Article 12

${ }^{58}$ Id Article 13, 17, 19, 21, and 22

${ }^{59}$ Id Article 14

${ }^{60}$ Id Article 23

${ }^{61}$ Implied on the preamble of the antiterrorism law.
} 
administration regulations, ${ }^{62}$ repealed the regular criminal procedural law ${ }^{63}$ and provides new evidentiary and procedural rules that serve as a tool for investigation and prosecution of terrorism. These rules, as later developments proved, become the bone of contention between the state and its critics.

In this regard, the proclamation, inter alia, gives the state intelligence service the right to intercept and circumvent individuals' conversation upon a court order ${ }^{64}$; the police- to conduct sudden ${ }^{65}$ and covert searches ${ }^{66}$ without court warrant, to arrest individuals without an arrest warrant ${ }^{67}$, and the right to detain individuals for an extended remand period $^{63}$; the public prosecutor - to present unsubstantiated evidences ${ }^{69}$ that eventually shifts the burden of proof to the accused individual; and the court- to admit unsubstantiated hearsay and indirect evidences ${ }^{70}$, which makes the indicted individual's ability to disprove allegations somehow impossible.

Critics amplifies these procedural provisions of the ATP as a major fault line in it that enables the State to compromise civil and political liberties in the name of countering terrorism. ${ }^{71}$ However, the government, oftentimes dismiss the critics accusing them as victims of double standard, which lacks a balance to compare the law with other countries anti-terrorism acts $^{72}$ - which is much aggressive in the states' view-or as an essential extraordinary rules that extraordinary crimes like terrorism necessitates ${ }^{73}$.

Thus, the major factor that triggers this case study is the impasse between this two contending views over the ATP. On the one hand, there is a plethora of academic and non-academic critics that litigates for an amendment or total repeal of the law and on the other hand, there is a government tirelessly defends the law in any ways possible. Who was/is subject of the ATP? How it was implemented? And what does terrorism trials in Ethiopia proves? Are some of the major questions the following analysis on one hundred twenty three $(\mathrm{N}=123)$ terrorism charges in

62 Ethiopian criminal Procedural code (1961), Proclamation No.185, Imperial Ethiopian Government

${ }^{63}$ Ibid

${ }^{64}$ Supra 55 Article 14

${ }^{65}$ Id Article 16

${ }^{66}$ Id Article 17

${ }^{67}$ Id Article 19

${ }^{68}$ Id Article 20

${ }^{69}$ Id Article 23

${ }^{70}$ Ibid

${ }^{71}$ See Supra 6.

${ }^{72}$ Sasahulh Yalew, A Comparative Review of Ethiopian and Western Anti-Terrorism Legislations (2010)

${ }^{73}$ Ibid 
Ethiopia-which constitutes nine hundred eighty five $(\mathrm{N}=985)$ individuals - in sixty six months research period, attempts to answer.

\section{Methodology of the Study}

This study blends an explanatory and exploratory approach of reaching to a problem. It tries to explain how Ethiopia's anti-terrorism legislation was/is implemented and at the same time, it explores the rationale behind the specific application of the law in specific cases. Hence, aimed at understanding the outreach of the law, the author employed various methods of inquiry. Consequently, trial observations, interviews, and criminal charge analysis are the major research methods adopted in doing so.

Regardless of the enactment of Ethiopia's anti-terrorism law on August 2009 — as per the research data testifies - the first cases in reference of it were brought to court on September $2011^{74}$ - two years after the adoption of the law and three months after the Ethiopian parliament designates five organizations - three domestic and two international-as terrorist groups, as per Article 2/4 and 25 of the ATP. Hence the court cases studied in this research covers the time span of five years and six monthsstretched from September 2011 to March 2017.

Nonetheless, gathering the research data was the most daunting part of the research. Especially, gathering terrorism charges brought to court. This was because inter alia, three main reasons.

The first and the foremost one is the total absence of publicly accessible data. Although, the Federal Democratic Republic of Ethiopia (hereinafter FDRE) constitution clearly provided that unless otherwise provided that, trials are public and criminal charges must be easily available to the public ${ }^{75}$, it is almost impossible to get terrorism related criminal charges from the states' archive. The lone public resource that could be consulted for the purpose of this research is the Ethiopian Year Book, published by the Federal Government Communication Affairs Office of Ethiopia-which is published annually for the past fourteen years. However, the year book barely mentioned data on terrorism and related trials. In fact, the $2013 / 14^{76}$ Year Book is the only one that mentioned the arrest of eighty

\footnotetext{
74 The first two terrorism related cases brought to court, citing the antiterrorism proclamations-on September 05, 2011-are the Elias Kifle et al $v$ the Federal Public Prosecutor and Abdiweli Mohammed et al $v$ the Federal Public Prosecutor. In both cases five Journalists are implicated.

${ }^{75}$ The cumulative reading of Article 19, 20, and 37 of the Federal Democratic Republic of Ethiopia's Constitution

${ }^{76}$ The year 2013/2014 is Ethiopia's 2006 as per the unique Ethiopian Calendar, which is neither Julian nor Gregorian. A year in Ethiopia has twelve even months each with thirty days and a thirtieth additional month with five days or six on every leap year.
} 
five individuals and who later brought to court alleged of terrorism and related activities. The rest of the Year Books mentioned actions taken by the police to counterterrorism in general terms that lacks specifics on the number of individuals arrested or/and the charge brought against them ${ }^{77}$.

The second challenge on the data gathering process was the enormousness of the cases and the gigantic number of individuals who are accused of terrorism, since September 2011. The lack of a centralized public archive along with the large amount of data makes the gathering cumbersome. Furthermore, while this research was developing new cases were brought to courts and that impacted the implication of the result of this study. Hence, the gathering requires a painstaking task designed to get the full picture of counterterrorism in Ethiopia.

To avoid a biased and half-baked result, the author employed a blanket-time based approach of data gathering. However, the lengthy research periods - five years and six months — was the third challenge the author find in employing an effective method of presenting the data. In this lengthy period, the state was jailing many individuals alleged of terrorism and the reasons given were numerous to decipher. Despite its advantage of reducing bias, the blanket approach has its own drawback. The foremost shortcoming was the regular update of new cases in which 2016 been a record year. Every time the state pressed a new terrorism charge against individuals that appears to affect/impact the result of the research. Hence, regular update and follow-up of the research data was challenging.

The data for this research was collected by directly accessing the criminal charges against individuals from the defendants themselves or/and from their representative and indirectly from reports that annotates terrorism charges brought by the Public Prosecutor in a reference to the ATP. By combining the directly accessed terrorism charges and the annotated reports along with in-person trial observations and refinement of the data, the author final tally stand on one hundred twenty three $(\mathrm{N}=123)$ terrorism charges that lists nine hundred eighty five $(\mathrm{N}=985)$ individuals/legal persons. Nonetheless, though this tally is the best that the author can collect, because of the aforementioned challenges, the author disclaim its exhaustiveness.

\section{Prosecution or Persecution: How the ATP was/is ab(used)?}

The Ethiopian legal system is not new to treat cases related with terrorism. Prior to 2009-before terrorism charges used to be pressed against Ethiopians and foreign elements alike, in reference to the old imperial Penal Code later amended as the Criminal Code in 2004.

\footnotetext{
${ }^{77}$ See for instance, Year Books for the year 2011/2012, 2012/2013 and 2014/2015.
} 
The repealed Imperial Penal Code of Ethiopia outlawed terrorism and terrorist methods in explicit terms ${ }^{78}$. The FDRE Criminal Code-which repealed and substitutes the Imperial Penal Code-copied the terms of the Penal Code and criminalizes acts of terrorism as criminal acts that would result rigorous punishments up to death ${ }^{79}$. As a result, prior to the adoption of ATP, the state used to press terrorism and related activities cases against individuals in numerous instances-referring to the two Criminal Codes ${ }^{80}$. That was one of the criticisms of the adoption of a distinct and separate antiterrorism law in Ethiopia. If the regular Criminal Code outlawed and criminalizes terrorism and if previous precedents demonstrate individuals' conviction, why Ethiopia needs a separate anti-terrorism law? Was one of the points noted by detractors of the enactment of Proclamation 652/2009. Ironically, in contradiction to its later action-justifying the adoption of a distinct anti-terrorism law-the Ethiopian government, in its 2002 report to the UN affirms the critics' position by indicating the adequacy of the Criminal Code to counter terrorism. ${ }^{81}$

This adequacy argument is somehow vindicated by recent court cases, in which we witnessed even after the enactment of the ATP that the state was/is sticking on the regular Criminal Code to incriminate individuals in some cases. The following three demonstrative cases would serve this fact better. The first of these cases is Tefera Mamo et al $v$ the Federal Public Prosecutor case. On December 2009, five months after the adoption of the ATP, yet before the House of People Representative proscribe five groups/organizations as terrorist organizations, the state brought a case against military officials like Brigadier General Tefera Mamo and thirty six other individuals (some of them were accused in absentia). Although, the alleged charges brought against the accused fits the provisions of ATP-in its later applicability mode-the plaintiff refrained from using it and sticks with the Criminal Code, in which the defendants were alleged of a crime of outrage against the Constitution ${ }^{82}$. Bekele Gerba et al $v$ the Federal Public Prosecutor is another case that validates the sates' reliance to the Criminal Code provisions. Bekele Gerba, a prominent Ethiopian politician was arrested on August 2011, three months after the Ethiopian Parliament designates three domestic and two international groups as terrorist organizations. Although, Bekele Gerba and co were accused of working for

\footnotetext{
78 Article 270 and 282 of the Ethiopian Imperial Penal Code (1957), Proclamation No. No. 158

${ }^{79} 258$ and 270 of the Criminal Code of Federal Democratic Republic of Ethiopia Criminal, Proclamation 4014/2004

${ }^{80}$ See Supra 35

${ }^{81}$ Supra 39

${ }^{82}$ Supra 79, Article 238
} 
the OLF-one of the terrorist designated groups-but, the state prefers to press a case against the defendants referring to the provision that criminalizes attack on the political and territorial integrity of the State under the Criminal Code. The same preference to the Criminal Code was demonstrated recently on the Dr. Merera Gudina et al $v$ the Federal Public Prosecutor case. Despite the fact that the three defendants and two media organizations in the case are accused of leading/working with the two of the five designated terrorist organizations - the OLF and Ginbot 7-only the latter two media houses has been accused of abetting terrorism, the rest are indicted of outrage against the constitution as per the criminal code of Ethiopia.

Thus, as the aforementioned cases and many other similar cases testifies, even long after the enactment of the ATP, the state still relied-in some instances - on the Criminal Code, which only makes the application of the ATP more confusing and inconsistent. The lack of explanation and justifications for such inconsistent application from the state, furthermore, opens the door wide to for speculation of the use and abuse of the ATP.

In spite of the state's reliance to the Criminal Code nonetheless, since September 2011, the dominant legal prosecution/political persecution in Ethiopia directly involves the anti-terrorism law.

\section{The data finding}

On September 05, 2011, the Federal Public Prosecutor brought two terrorism related charges in reference to the anti-terrorism law. The first case involves five defendants (journalists) under Elias Kifle et al $v$ the Federal Public Prosecutor - in which the defendants were accused of communication with members of Ginbot 7 Movement for Unity, Democracy and Justice. The second case brought to the Federal High court on the same days was the Abdiweli Mohamed et al $v$ The Federal Public Prosecutor case-in which the defendants were accused of being a member of the ONLF and abetting its terrorist activities. The latter case involves two Swedish Journalists who enters to Ethiopia to report $^{83}$ on the humanitarian crisis in the restive Ethiopian Somali Region ${ }^{84}$.

The two cases that involved nine individuals were the first publicly reported and known cases brought to court as per the ATP. Out of the nine defendants, five of them were journalists. The fact that the law starts to be

\footnotetext{
${ }^{83}$ Martin Schibbye and Johan Persson, 438 Days, (2013)

${ }^{84}$ Somali Regional State is one of the nine regions established by the FDRE Constitution in 1995. According to the Human Right Watch the Ethiopian government is committing "war crime" and "crimes against humanity" in the area. See Human Rights Watch, Collective Punishment War Crimes and Crimes against Humanity in the Ogaden area of Ethiopia's Somali Regional State The region (2008)
} 
implemented by accusing journalists was somehow considered as a vindication for the many critics of it. ${ }^{85}$ Contrarily, the state often fires back to such allegations by denigrating the criticisms to ideological squabbles ${ }^{86}$.

Since the first cases of terrorism-referring the ATP-brought to court on September 2011, its effect snowballed and every year set a new record number of defendants. According to the finding of this research in the past sixty six months-from September 2011 to March 2017-the Ethiopian government files one hundred twenty three $(\mathrm{N}=123)$ separate terrorism charges referring, exclusively to the anti-terrorism law, in which nine hundred eighty five $(\mathrm{N}=985)$ defendants are implicated. Out of these cases fourteen $(n=14)$ of them are filed against lone individuals who were/are accused of being member and/or rendering support to designated/undesignated terrorist groups ${ }^{87}$. The rest one hundred nine ( $\mathrm{n}=$ 109) cases constitute two or more individuals with the highest listed seventy seven individuals in a single charge ${ }^{88}$.

\footnotetext{
${ }^{85}$ In the first of the two cases, brought on September 05, 2011, Elias Kifle et al vs the Federal public Prosecutor, three of the five defendants are Journalist. Similarly in the second terrorism case filed in the same day, Abdiweli Mohammad et al $v$ the Federal public Prosecutor, two of the four defendants are Journalists.

${ }^{86}$ See Supra 72

${ }^{87}$ The fourteen cases are Ahmed Mustafa v The Federal Public Prosecutor, Amanuel Desta $v$ The Federal Public Prosecutor, Anteneh Tadesse $v$ The Federal Public Prosecutor, Befekadu Abebe $v$ The Federal Public Prosecutor, Bachu Merega v The Federal Public Prosecutor, Demeke Zewde $v$ The Federal Public Prosecutor, Fasika Getachew $v$ The Federal Public Prosecutor, Getachew Shiferawv The Federal Public Prosecutor, Hassen Dawud $v$ The Federal Public Prosecutor, Ligabaw Girmaw $v$ The Federal Public Prosecutor, Mamuye Diro v The Federal Public Prosecutor, Mohammad Abdulkadir v The Federal Public Prosecutor, Tesfaye Kiros v Tigray Regional State Public Prosecutor, and Yonatan Tesfaye $v$ The Federal Public Prosecutor

${ }^{88}$ In the Miftah Shiek Surur et al v the Federal Public Prosecutor case, the state pressed a terrorism charge against seventy seven Prisoners of War in a single file.
} 
The total studied cases categorized in different variables (From September 2011 to March 2017)

\begin{tabular}{|c|c|c|c|c|c|c|c|}
\hline $\begin{array}{c}\text { Total } \\
\text { number } \\
\text { of } \\
\text { cases* }\end{array}$ & $\begin{array}{c}\text { Number of } \\
\text { defendants** }\end{array}$ & \multicolumn{2}{|c|}{ Sex ratio } & \multicolumn{2}{|c|}{ Nationality } & \multicolumn{2}{|c|}{$\begin{array}{c}\text { No. of 'terrorist } \\
\text { organizations' } \\
\text { implicated in the } \\
\text { cases*** }\end{array}$} \\
\hline \multirow{2}{*}{$\mathrm{N}=123$} & $\mathrm{~N}=985$ & Male & Female & Ethiopians & $\begin{array}{c}\text { Non- } \\
\text { Ethiopians }\end{array}$ & Proscribed & $\begin{array}{c}\text { Non- } \\
\text { proscribed }\end{array}$ \\
\cline { 3 - 8 } & $\begin{array}{c}\mathrm{n}= \\
967\end{array}$ & $\mathrm{n}=18$ & $\mathrm{n}=954$ & $\mathrm{~N}=31$ & $\mathrm{n}=5$ & $\mathrm{n}=10$ \\
\hline
\end{tabular}

*By cases, the researcher is referring those criminal cases filed to the Federal High Court of Ethiopia-and in two different circumstances to the Amhara Regional State Supreme Court and the Tigray Regional State Supreme Court-as per the jurisdiction vested by the anti-terrorism Proclamation.

** The number of defendants is an aggregate of the total of individuals who are accused of terrorism as per the anti-terrorism Proclamation in the research period.

*** These organizations are groups, which are proscribed as 'terrorist organizations' by the House of Peoples Representative on June 2011 and other groups which are not essentially designated by the house, but implicated as terrorist organizations on the studied court cases.

Legal personality wise, the ATP under Article 2/17 provided that 'person' refers to either physical or juridical person. Hence, out of the total research population $(\mathrm{N}=985)$ accused of terrorism in the research period, four $(n=4)$ of them are juridical persons ${ }^{89}$ and the rest nine hundred eighty one indictees are physical persons. On the other hand, out of the total research population $(\mathrm{N}=985)$, the state pressed terrorism charges against forty one $(n=41)$ individuals in absentia-in which the defendants are neither not in Ethiopia nor their specific address was identified on the charges. The rest nine hundred forty four $(n=944)$ defendants were charged after their actual arrest or freeze of their operation in case of the juridical persons.

When we see the citizenship of the defendants, the charges testified that thirty one $(\mathrm{n}=31)$ individuals who were accused of terrorism since September 2011 are not Ethiopians ${ }^{90}$ and two juridical persons $(n=2)$ accused of rendering support for terrorism are US based Media Houses ${ }^{91}$.

\footnotetext{
${ }^{89}$ In Abubaker Ahmad et al $v$ the Federal Public Prosecutor case the prosecutor accuses Albir Development and Neme'ae NGO as organizations abetting terrorism and similarly in the Ethiopian Satellite Television and Oromia Media Network $v$ The Federal Public Prosecutor case the state pressed similar charges against two US based juridical persons, the Ethiopian Satellite Television and Oromia Media Network.

${ }^{90}$ Those non-Ethiopians the research found in the list includes two Kenyans, one American, ten Somalians, eleven Eritreans, four from the UK, two Swedes, one South Sudanese, and one Norwegian.

${ }^{91}$ Supra 89
} 
The rest nine hundred fifty two $(n=952)$ defendants are either Ethiopian nationals or juridical persons legally registered in Ethiopia. This constitutes more than ninety six percent of the total number of the research population. Accordingly, the finding suggests the ATP was/is targets ninety six Ethiopians for every one hundred terrorism indictees.

Gender wise, more than ninety eight percent of the defendants are male-in which the research finds eighteen female defendants $(n=18)$ compared with nine hundred sixty seven male counterparts $(n=967)$. On the other hand, in all the one hundred twenty three cases $(\mathrm{N}=123)$, fifteen ${ }^{92}$ different—ideologically and operationally—groups $(\mathrm{N}=15)$ are explicitly named as terrorist groups by the state, including the five $(n=5)$ officially proscribed groups on June 2011.

Saying this as a general remark-for further information on the studied cases see Appendix 1-on the finding, the next step was categorizing the data in certain frames and variables, hence it makes the inquiry understandable. The following topics will try to delve with these specifics.

\section{Proscription enables prosecution/persecution}

The proclamation under article 25 empowered the House of Peoples Representative to proscribe any organization that commits acts of terrorism; prepares to commit acts of terrorism; supports or encourages terrorism; or is otherwise involved in any terrorism activities as a 'terrorist organization'. The demonstrated understanding of this power of proscription is, the executive organ - the government-will submit its own list to the house and the house will approve/dismiss it. Practically, in the whole research periodfor that matter since the adoption of the law in 2009-the parliament convened only once for designation purpose-on June 2011 - and proscribed five groups as 'terrorist organizations'. These groups are Ginbot 7 for Justice, Freedom and Democracy, Ogaden National Liberation Front (ONLF), Oromo Liberation Front (OLF), Al-Qaeda, and Al-Shabaab. Whereas the former three are disgruntled Ethiopian rebel groups battling for the ouster of the regime in power, the latter two are a UN designated International terrorist groups ${ }^{93}$. This blanket approach-discussed in

\footnotetext{
92 These organizations/groups are Al-Qaeda, Al-Shabaab, Amhara Democratic Union Front, Benishangul People Liberation Movement, Ethiopian People Patriotic Front, Ferketul Linajiya Muslim Juma, Gambela Democratic Movement, Gambela People Liberation Movement, Ginbot 7 for Justice, Freedom and Democracy, Islamic State in Iraq and Syria, Jum'atitu Muslim Jihadi, Khawarij, Ogaden National Liberation Front, Oromo Liberation Front, and Tigray People Democratic Movement.

${ }^{93}$ Although the UN has no formal list of designated terrorist groups, in 1999, the UNSC listed the Al Qaeda group as a terrorist organization as per resolution 1267 and similarly, the Al Shabaab terrorist group was also listed by the UN as a terrorist group since 12 April, 2010 as per UNSC resolution 1844, 2008.
} 
subsequent topics in detail—was subjected to many criticisms ${ }^{94}$ however. Apparently, the ATP began to be implemented days after the parliament designates the aforementioned five organizations as terrorist organizations, on June 2016.

Out of the total —one hundred twenty three ( $\mathrm{N}=123)$ — cases studied, one hundred of the cases $(n=100)$ directly involves one of the five designated 'terrorist organizations'. This represents more than eighty one percent of the total terrorism charges pressed by the state. On the other hand, ninety four $\left(n \_i=94\right)$ of the one hundred $(n=100)$ cases are pressed against the three Ethiopian rebel groups-Ginbot 7, OLF, and ONLF-which is more than ninety three percent of the all the terrorism charges pressed against the designated groups.

In some cases the prosecutor mingled two or more designated groups-which are ideologically and tactically competing and different-in a single charge. For example, in the Masresha Sete et al $v$ the Federal Public Prosecutor case, the state filed a case against thirty eight remand prisoners accusing them as members of three different designated groups namely, OLF, Ginbot 7, and Al Shabaab, simultaneously. In the Soliana Shimeles et al $v$ the Federal Public Prosecutor case the state present a case against ten bloggers and journalists mentioning they have connection with two different proscribed terrorist groups, Ginbot 7 and OLF, concurrently. In the Ethiopian Satellite Television and Oromia Media Network $v$ The Federal Public Prosecutor case the prosecutor general present a case against two Media Houses, Ethiopian Satellite Television and Oromia Media Network accusing them of rendering terrorist activities by Ginbot 7 and OLF, respectively. This messy and concurrent accusation of different individuals as linked with organizations exist within a different ideological and tactical realm appeared to be a very challenging thought task to comprehend.

Further, as the research finding indicates, the fact that eighty one percent of the total terrorism criminal charges filed in reference to the antiterrorism law directly referred to the proscription clause provided by of the law, which later was executed by the federal chamber by proscribing five groups as terrorist organizations, with no further qualification. This eases the task of the public prosecutor immensely and shifts the burden of clearing self from the accusations to incarcerated individuals.

In this regard, in the Andualem Aragie et al $v$ the Federal Public Prosecutor case, the state filed a single terrorism case against twenty four activists, politicians and journalist—in which the plaintiff failed to show a

\footnotetext{
${ }^{94}$ See Asmelash Yohannes Teklu (PhD), Enhancing Human Rights Protection and National Security by Proscribing a 'Terrorist' Organisation: the Ethiopian Dilemma, Mekelle University Law Journal, Volume 4, June 2016.
} 
modicum of evidence about how all the defendants could be accomplicesmerely by mentioning Ginbot 7, one of the designated groups-as a glue. Yet again, in the Gurmesa Ayano et al v the Federal Public Prosecutor case, a terrorism criminal charge was filed against twenty three individuals, in which some of them are vocal critics of foco and insurrection ${ }^{95}$-by a mere mention of OLF, one of the proscribed 'terrorist groups' - as a common denominator. Similarly, in the case Abdiweli Mohammad et al $v$ the Federal Public Prosecutor, the state instituted a terrorism charge by merely referring to one of the five proscribed terrorism groups-ONLF-and filed a case against four individuals, in which two of them happened to be foreigners, who are by any measure could not be part of the rebel group which is rebelling for the right of the Ogaden clan in Ethiopia. Hence, the sweeping designation rule enshrined under the ATP followed by the parliamentary measure to proscribe certain Ethiopian disgruntled rebel groups along with International terrorist groups proved to be the main tool that enables the state to crackdown dissidents and opposing voices alike.

The research finding, more over shows that in more than seventy percent of the cases — six hundred ninety nine persons $(n=699)$-in the research period, are individuals who are indicted of being members and rendering support to either the Ginbot 7 or the OLF rebel groups. Consequently, the (mis)application of the anti-terrorism law in reference to the proscription clause is more glaring on cases that involve members of the legally registered political parties and journalists accused of far-fetched connection with these two groups. (The author further discussed this issue in the subsequent topics).

Still looking deep to the cases, we found that forty five percent of all the cases are brought against individuals who are accused of leading and abetting the Ginbot 7 designated group. In this regard, in many of the cases the state alleges individuals who are members of legally registered political parties as perpetrators. For example, in the Getachew Mekonnen et al $v$ the Federal Public Prosecutor case, the state filed a terrorism charge against sixteen individuals who are members of the legally registered All Ethiopians Unity Party (hereinafter AEUP), Blue Party, and Unity of Democracy and Justice Party (UDJ) - by conflating Ginbot 7, a proscribed group and the Amhara Democratic Unity Movement, an undesignated, but later labeled as a terrorist group by a court — as groups linked with the aforementioned legally registered political parties. Similarly, in the Zemene Miheret et al $v$ The Federal Public Prosecutor file, the state takes the same approach of indicting leaders of AEUP as terrorists linked with Ginbot 7 designated group. In

\footnotetext{
${ }^{95}$ Notably, the fourth defendant of the case, Bekele Gerba was known for his hard belief on nonviolent struggle and oftentimes denouncing violence of any kind.
} 
other instance, in Elias Kifle et al $v$ The Federal Public Prosecutor case, in which the state pressed a charge against five individuals - three of them are journalists-associating them with the same group, Ginbot 7.

Rating the five organizations_-based on their political Manifestos—which are designated by the Ethiopian House of Peoples Representative, on June, 2011 as 'terrorist organizations' through "The Seven Part Definitions" of terrorism as framed by Louise Richardson*

\begin{tabular}{|c|c|c|c|c|c|c|c|}
\hline $\begin{array}{c}\text { Name of } \\
\text { the } \\
\text { proscribed } \\
\text { group }\end{array}$ & \multicolumn{9}{|c|}{ Activities } \\
\cline { 2 - 8 } & $\begin{array}{c}\text { Politically } \\
\text { motivated }\end{array}$ & Violent & $\begin{array}{c}\text { Non- } \\
\text { state } \\
\text { actors }\end{array}$ & $\begin{array}{c}\text { Symbolic } \\
\text { attack } \\
\text { and } \\
\text { victims }\end{array}$ & $\begin{array}{c}\text { Against } \\
\text { Civilians }\end{array}$ & $\begin{array}{c}\text { The } \\
\text { message } \\
\text { not } \\
\text { victory }\end{array}$ & $\begin{array}{c}\text { Victims } \\
\text { and } \\
\text { audiences } \\
\text { are } \\
\text { different }\end{array}$ \\
\hline Al Qaeda & $\checkmark$ & $\checkmark$ & $\checkmark$ & $\checkmark$ & $\checkmark$ & $\checkmark$ & $\checkmark$ \\
\hline $\begin{array}{c}\text { Al } \\
\text { Shabab }\end{array}$ & $\checkmark$ & $\checkmark$ & $\checkmark$ & $\checkmark$ & $\checkmark$ & $\checkmark$ & $\checkmark$ \\
\hline OLF & $\checkmark$ & $\checkmark$ & $\checkmark$ & X & X & X & X \\
\hline ONLF & $\checkmark$ & $\checkmark$ & $\checkmark$ & X & X & X & X \\
\hline Ginbot 7 & $\checkmark$ & $\checkmark$ & $\checkmark$ & X & X & X & X \\
\hline
\end{tabular}

*What Terrorists Want: Understanding the Enemy, Containing the Threat, November 13, 2007

Likewise, twenty eight percent of all the cases were pressed against individuals who are accused of leading and abetting the OLF designated group. Nevertheless, as like as those cases brought against Ginbot 7, in many of the cases that involve OLF, the state conflates legally registered political parties with the proscribed groups. For example, in the Gurmessa Ayano et al $v$ The Federal Public Prosecutor case, the prosecutor pressed a terrorism charge against twenty two members of the Oromo Federalist Congress-a legally registered political party — alleging them of membership to the OLF by merely citing the proscription clause under the ATP. Similarly, in the Desta Dinqa et al $v$ The Federal Public Prosecutor case the prosecutor followed a same approach of conflation. Furthermore, In the Yonatan Tesfaye et al $v$ The Federal Public Prosecutor case, a terrorism charge that begs a rendering support for the OLF was instituted against Yonatan Tesfaye, a member of Blue party—a legally registered political party—citing the ATP's designation clause.

In a stark contrast, in the research period, the state pressed a terrorism charge against two of the designated terrorist groups-Al Qaeda and Al Shabaab-only in less five percent of the total cases, in which the state instituted six $(n=6)$ terrorism charge against individuals—even in those 
cases the absolute majority of the defendants are Ethiopians-accusing them of having connection with the Al Shabaab terrorist group in Somalia. For instance, In the Jafar Mohamed et al $v$ the Federal Public Prosecutor case, seven Ethiopian defendants are accused of attempting to join the Shabaab terrorist groups. Similarly, In the Hassen Jarso et al $v$ the Federal Public Prosecutor case, the prosecutor brought a terrorism charge against eleven individuals - ten of them are Ethiopians-for being members of the same terrorist group citing the proscription clause.

To sum up, of the total studied cases in the research period, more than eighty one percent of the cases assert their legitimate ground against the defendants referring to the proscription clause under Article 25 of the ATP. This proved the pivotal role the June 2011 designation of five groups as terrorist organizations played on. On the other hand, out of the total cases brought against the proscribed groups, ninety five percent of the cases are brought against Ethiopian power contending rebel groups designated as 'terrorist organizations' and out of the total defendants included in this research more than ninety eight percent of the accused are Ethiopian nationals. Contrastingly, the finding suggests, unlike other countries and the global trend-of targeting foreigners by anti-terrorism laws-Ethiopia's ATP mainly targets Ethiopian organizations and Ethiopian nationals, in which Foreign Terrorist Organizations and international terrorists are barley indicted of and seldom implicated. Hence, the proscription clause which was take in to force in a sweeping and targeting Ethiopians fashion vindicates the critics of the law from its very inception and it opens the door wide for political persecution.

\section{'Terrorists' beyond proscription}

Notwithstanding that the major terrorism court cases are brought against the two proscribed groups, as the previous discussion indicates, however, among other things, one of the other major finding of the research on the application of the anti-terrorism law is its implementation against groups that are not designated as terrorist organizations by the federal chamber. During the research period, the state brought numerous terrorism cases against individuals mentioning ten undesignated groups; the Amhara Democratic Union Front, Benishangul People Liberation Movement, Ethiopian People Patriotic Front, Ferketul Linajiya Muslim Juma, Gambela Democratic Movement, Gambela People Liberation Movement, Islamic State in Iraq and Syria, Jum'atitu Muslim Jihadi, Khawarij, and Tigray People Democratic Movement.

Article 2/4 of the ATP defined a "terrorist organization" as a group, association or organization which is composed of not less than two members with the objective of committing acts of terrorism or plans, prepares, 
executes or cause the execution of acts of terrorism or assists or incites others in any way to commit acts of terrorism; or an organization so proscribed as terrorist by the parliament pursuant to Article 25 of it. Hence, the law prescribes a wide and open definition of terrorist organizations - as any group who aimed to commit the widely listed terrorist acts under Article 3 of the proclamation or any group designated as a terrorist group by the Federal parliament.

The research finds that about twenty percent - twenty three cases (n = 23) — of the total terrorism related-one hundred twenty three $(\mathrm{N}=123)$ charges brought against individuals, in reference to the ATP are cases mentioning undesignated groups, which are considered as terrorist organizations by the plaintiff as per Article 2/4/a of the ATP. Among these ten groups nine of them are Ethiopian groups, which testify the fact that still the application of the ATP over undesignated groups is mainly focused on Ethiopian nationals.

Regarding the indictment of individuals alleged of abetting the work of undesignated terrorist groups, in the Abubakar Ahmed et al $v$ the Federal Public Prosecutor case for example, a terrorism case was brought against twenty nine Ethiopian religious activists, leaders and journalists and two religious organizations, in which the state labeled a peaceful religious right protest movement ${ }^{96}$, Dimitsachin Yisema as a terrorist organization and allege the defendants as the leaders of it. Similarly, in the Piliman Kuwot et al $v$ the Federal Public Prosecutor case, the prosecutor pressed a terrorism case against ten parliamentarians and state officials associating them with a disgruntled rebel group_-Gambela People Liberation Movement-which is labeled by the executive (not the parliament) as a terrorist group. Likewise, in the Abdulkerim Abdusemed $v$ the Federal Public Prosecutor case, seven individuals are accused of being members of another disgruntled rebel group-the Benishangul People Liberation Movement-even though undesignated by the parliament, but the prosecutor labeled it as a terrorist organization pursuant to Article 2/4/a of the ATP.

Thus from the studied cases we can conclude that, the very application of the ATP in one out of every five cases targets groups which are not proscribed as terrorist organizations by the parliament and in all the cases, except one it was applied against Ethiopian groups or collectives.

\footnotetext{
96 See, Human Rights Watch, Ethiopia: Prominent Muslims Detained in Crackdown, available at https://www.hrw.org/news/2012/08/15/ethiopia-prominent-muslims-detainedcrackdown , (August 2012)
} 


\section{One-sized law-one-sized application}

Out of the many criticisms of the Ethiopian anti-terrorism law, its widely written drafting and the blanket conflating approach it followed are the principal ones. The law failed to make specific treatment to Foreign Terrorist Organizations (hereinafter FTOs), international terrorism, domestic terrorism, and home grown extremism is one of the most vocal disapproval against it. Hence, one of the studied topics on the application of the ATP in this research was the question of how the law treated these different, but related notions of terrorism and related activities.

For the purpose of this research FTOs are defined as groups/powers based abroad-not in Ethiopia-but working to hamper Ethiopia's interest using a terroristic tactic; International terrorists are groups/powers located inside Ethiopia, but inspired by and take direction from a FTOs or foreign power/s; Homegrown violent extremists are on the other hand, those who are inspired by, but do not take direction from, FTOs; and Domestic terrorists are those who are not inspired by, and do not take direction from, a foreign terrorist organization or foreign power and working against Ethiopia's interests employing terroristic tactics. ${ }^{97}$ By 'terroristic activity', the author is referring to those acts, which fulfilled the three main elements of terrorism; essentially violent, aimed at a certain ideological end, and targeting civilians.

The ATP failed to identify these different kinds of groups, by rather taking a very general approach of defining every group in a single term. When we see the application, beyond the main targets of the ATP-rebel groups, activists, and writers-we get cases the ATP was/is used against each of the aforementioned four groups. For instance, in the Aman Assefa et al $v$ the Federal Public Prosecutor case, a terrorism charge was pressed against twenty seven individuals in which some of the leaders are trained abroad - in Somalia_by a FTO_Al Shabaab-and attempted to commit a terrorist act in Ethiopia and against Ethiopia's interest abroad. Likewise, in the Abdulwahid Abdela et al $v$ the Federal Public Prosecutor case, the state accuses twenty individuals as groups inspired by the international terrorist group named Islamic State in Iraq and Syria otherwise known as ISIS and conspires to commit a terrorist act in Ethiopia. Contrastingly, in cases like Bederu Ababor et al $v$ the Federal public Prosecutor, the plaintiff pressed a terrorism charge against nine individuals accusing them for domestic terrorism. Furthermore, in the Mohammad Abdulkadir $v$ Federal public Prosecutor case, the state charges a lone individual with terrorism alleged of proselyting a violent homegrown extremism. One thing that makes the

${ }^{97}$ For more detailed discussion on this categorization, see, Susan Hennessey, The Good Reasons to Not Charge All Terrorists With Terrorism, available at https://www.lawfareblog.com/good-reasons-not-charge-all-terrorists-terrorism, (2015) 
aforementioned four instances common is that the state uses the same provisions of the ATP by conflating the different features and motive of each different cases and associated group, which eventually eases the state's burden to prove the cases against defendants.

This prosecutorial policy of melting every kind of political violence/activity in the same pot of terrorism boarders' persecution than prosecution and endangers civil and political liberties enshrined under the FDRE constitution. The ATP amplified and implied a single understanding of each of aforementioned groups and the application of it takes a similar approach as it was demonstrated in many similar cases. This raises a question over the effectiveness of the law to countering terrorism by uprooting 'real terrorists' from the breeding ground.

\section{High vulnerability of dissidents}

The other aspect of the research finding suggests a certain visible pattern on the identity of group of 'victims' people who are indicted as per the anti-terrorism law. The Proclamation's over broad and sweeping provisions executed by an approach that enables the state to lodge a terrorism case against possibly any one dissenting makes some group of people more prone to be labeled as terrorists and ultimately convicted of it.

As it tried to indicate in the above topics, the ATP was mainly - in more than seventy percent of the total cases and in more than seventy percent of the defendants - used against two major dissident groups-Ginbot 7 and the OLF-who rebelled against the state. However, in one third of the cases, the state accuses writers, rights activists, and members of legally registered political parties citing the ATP and associating them-though in many of the cases the defendants decried against the tactics employed by the two groups who aspire to overthrow the EPRDF led regime in Ethiopia-mainly with the two rebel groups. This again is a problem directly related with the sweeping proscription rule discussed above. Proscribing political insurgent groups aspired to oust the regime in power along with Foreign Terrorist Organizations opens the door wide to devour dissidents of all sort-by making them part of those designated groups.

Hence, the proclamations seldom application (only less than five percent of the cases) against FTOs and international terrorist, on the one hand and its inflated overstretch to political activists and writers in a very visible and clear fashion calls for inquiring the motivating factor behind its enactment and raise doubt on the necessity of it to tackle terrorism. Ultimately, this fact begs us to ask, is this law designed to prosecute terrorists or to persecute dissent? 


\section{Janus-faced law: but why?}

Leaving the academic arduous and unresolved discourse over the meaning of terrorism, it is widely agreed that the menace of terrorism is universal and a threat to every nation. Ethiopia as a sovereign nation has all the right to securitize its citizens and to fight terrorism tooth and claw. Furthermore, classifying terrorism as a sui generis and treating in that sort distinctly is all essential and sanely understandable. However, as far as the extent of the threat of terrorism to the national interest of Ethiopia, there is a big discrepancy among scholars and commentator.

Although, the Ethiopian government justifies the adoption of a counterterrorism law and establishment of a national anti-terrorism team citing 'hundreds of terrorist attacks' in the past two decades ${ }^{98}$, many doubts this claim as a politically inflated assertion. To the vindication of the later, in some instances, the Ethiopian government was implicated in fake terrorist plots to justify its sweeping counterterrorism strategy. ${ }^{99}$ Nonetheless, in spite of such criticism, some scholars praised the way the Ethiopian government deals with terrorism by employing para-military strategies ${ }^{100}$.

For commentators and writers like David Shinn, the current strategy has a mixed feeling in which he remarked that, "Ethiopia has every right to respond harshly to acts that are clearly terrorist[ic] in nature. Most countries would do the same thing [...] Ethiopia has the right to stop terrorist groups such as al-Shabaab from conducting acts inside Ethiopia. It has generally been successful at preventing terrorist attacks by non-Ethiopian groups reside [...] outside the country." However, he retorted that "[t]he problem is applying the definition of terrorism to acts where it just does not apply. More importantly, I would like to see Ethiopia make a much greater effort to respond to root causes of terrorism such as emphasizing the rule of law, permitting a relatively free press, and allowing greater scope to express dissent peacefully. Economic development is also important, especially when it benefits all elements of society." 101

Contrastingly, Dr. Yakob Hailemariam, a leading lawyer and politician expressed his deep concern about the very need the law, the harsh implementation of the ATP, and the whole counterterrorism strategy the

\footnotetext{
98 See Supra 28 vis-à-vis Global Terrorism Database 43 years report available at https://www.start.umd.edu/gtd/search/Results.aspx?search=Ethiopia\&sa.x=31\&sa.y=17\&sa $=$ Search

99 Thomas C. Mountain, Ethiopia Bombs Itself, Blames Eritrea available at https://www.foreignpolicyjournal.com/2011/09/16/wikileaks-ethiopia-files-ethiopia-bombsitself-blames-eritrea/, (2011)

${ }^{100}$ Mehari Taddele Maru, The secret to Ethiopia's counterterrorism success, available at, http://www.aljazeera.com/indepth/opinion/2015/07/secret-ethiopia-counterterrorismsuccess-150728112317438.html

101 The author's Interview with Ambassador David Shinn (December 2016)
} 
Ethiopian government is currently implementing. Yakob argues that, "based on empirical and practical evidences the extent of terrorism threat to Ethiopia is an exaggerated thing, which can be quelled using the regular criminal laws as it used to be."102 Furthermore he adds the current approach of countering terrorism in Ethiopia as a very flawed approach that misses its targets and collaterally victimizes dissidents.

The ATP was adopted in the middle of such debates from both sides. Up on its implementation it proved that it mainly targeting Ethiopian dissident groups - in large majority of the cases — and only used to prosecute individuals accused of abetting and conspiring for Foreign Terrorist Organizations (FTOs) in less than five percent of the total cases. Although some of the cases against FTOs can be corroborated by ample evidences ${ }^{103}$, in some other cases, there is still a cloud of clarity on the cases pressed against some individuals implicated in association with the FTOs ${ }^{104}$.

Hence, the sweeping implementation of the widely spelled Ethiopian anti-terrorism law which was justified as a tool designed to make the security apparatus effective in countering terrorism inflicts a problem on the whole political and legal landscape. This begs us to examine the two contradictory Janus-faced features of the ATP going through major takeaways of its implementations.

The first takeaway from the implementation of the ATP is a sense of weaponized law-laws that targets and struck those individuals and organs that are not abided with political willingness of those in power. Based on the data in the research, the most sensible takeaway is the persistent trend of targeting disgruntled political groups and dissidents of every kind by extension. This led us to the conclusion that the ATP-unlike what it promised to do-is highly abused in a manner of targeting specific political groups and ideas who has nothing to do with the essential understanding of terrorism or violence for that matter.

In this regard the ATP is serving the state as one of those lois scélérates, which are enacted in the past decade in Ethiopia ${ }^{105}$. The main similar features of these laws are their targets. Most of these laws are

\footnotetext{
102 The author’s Interview with Dr. Yakob Hailemariam (January 2017)

103 The authors prison conversation with Hassan Jarso Kotola, a Kenyan national and a member of Al-Shabaab terrorist group, who is sentenced for 17 years of rigorous imprisonment in Ethiopia (May 2014)

${ }^{104}$ The author's prison conversation with Anus Mohammad, a Somali national who is sentenced for 9 years of rigorous imprisonment in Ethiopia (2015)

105 Among these laws, the Freedom of the Mass Media and Access to Information Proclamation No. 590/2008 Charities and Societies Proclamation No. 621/2008, the Antiterrorism Proclamation 652/2009, and A Proclamation to provide for the Electoral Code of Conduct for Political Parties No. 662/2009 are the most notable ones.
} 
targeting political opponents and writers of all sorts for politically motivated reasons. The anti-terrorism law plays a leading role in this effort.

The other takeaway from the application of the ATP is its execution, which mainly motivated to delegitimize dissent of every kind. In the large majority of the cases, individuals are indicted of terrorism for trivial or no reasons. The general and vague terms of the law followed by its sweeping application, makes it easy for the state to use terrorism as a deligitimization tool against dissidents. Given the fact that terrorism is a universal pejorative term-once political operatives, activists, and writers are labeled as 'terrorists' by the law, it is tough for them to clean their tarnished good will and eventually they will lose legitimacy among their constituency or/and from the international community.

The third intended result from the sweeping implementation of the Ethiopian anti-terrorism law is the state's aspiration to gain legitimacy in the name of countering terrorism. By prosecuting as many individuals as possible as terrorists, the Ethiopian government implies it is fighting terrorism tooth and claw and this effort presumably garners support and allies from within Ethiopia and outside of it. Eventually, the persecution will establish legitimacy to the Ethiopian regime, which is subject of numerous criticisms and challenged by many political forces.

\section{Overstretched counterterrorism strategy and its discontent}

Although, tackling terrorism is a daunting undertaking that needs an orchestrated legal, prosecutorial, intelligence, and military efforts, nonetheless it also needs to be a meticulous and focused task. It is a universal phenomenon that in the name of countering terrorism states are seen compromising basic rights and liberties enshrined under their legal system $^{106}$.

As this paper tries to point out the application of Ethiopia's antiterrorism law is an epitome of misusing counter terrorism as an excuse for violation of human and democratic rights as well as silencing dissidents. During the research period-from September 2011 to March 2017-the state overused the anti-terrorism law and prosecute as many as one thousand individuals. In a staggering majority, in more than ninety five percent of all the cases terrorism charges are lodged against individuals who are alleged of leading and abetting Ethiopian disgruntled insurgent groups. Still in third of all the cases, the state pressed a terrorism allegation against civilians who has nothing to do with either terrorism or the rebel groups.

Beyond this appalling persecution of dissidents, the blatant and abysmal misuse of the law and exploitation of the universal cause,

${ }^{106}$ Supra 6 
counterterrorism however, has far-reaching legal as well as political consequences.

The first and the foremost effect of this legally misused counter terrorism strategy is its bad implication to the whole notion of terrorismwhat this author calls it hackneyed terrorism. Hackneyed terrorism is an understanding of terrorism as an insignificant and overused act/concept. Because of the state's high reliance and mis(over)using of the anti-terrorism law in silencing dissidents, the populace will lack the alertness as well as the readiness in joining counterterrorism efforts.

The second impact of the sweeping usage of anti-terrorism law as the Ethiopian case suggests ironically on the counterterrorism allies. Terrorism is essentially not an act that a certain lunatic did for personal reasons. Rather, it is deep rooted in the realm of ideology. Thus, an effective counterterrorism strategy calls for a wider public in tackling the ideological pillars of terrorism. Nevertheless, in Ethiopia, as this research finds, the state is targeting those individuals who should are supposed to be primary partners in the counterterrorism alliance-activists, writers, and revered political figures - by the law that is actually expected to countering terrorism. This backfires and it will result a long lasting effect on the overall strategy.

Thirdly, implementing a widely written law in an overstretched manner as it is implemented in Ethiopia would blow away the general populaces trust on the justice machinery and eventually, it will make the 'Criminal Justice Model' of countering terrorism unusable. The Criminal Justice Model mainly intended at maintaining peace and order and countering terrorism in a designated community-by using criminal prosecutorial platforms. However, when the state weaponized laws to attack political foes and rebellious elements alike, using laws designed to counter terrorism, the trust and adherence towards the system will fade away.

Last but not least, the sweeping implementation of the anti-terrorism law against any one opposing the status quo in Ethiopia also calls for a growing disregard of International obligations that Ethiopia is part of. Among the many obligations that are worthy of insight, we found the Geneva Conventions on the law of war that Ethiopia is a signatory and part of it. In some of the terrorism charges lodged against Ethiopians citing the anti-terrorism law, Prisoners of War are involved. These are individuals who are captured in the battlefields and later indicted with terrorism, irrespective of their status and their individual circumstances as per the Geneva Conventions on law of war that covered insurgencies ${ }^{107}$.

\footnotetext{
${ }^{107}$ Ethiopia is a signatory and part of all the four 1949 four Geneva Conventions on the law of War and among the 1977 three amendment protocols, Ethiopia is a party to the two protocols, in which Protocol II-relating to the Protection of Victims of Non-International Armed Conflicts that includes protection of insurgent groups at war-is included.
} 
Generally, though the Ethiopian anti-terrorism law is a widely opened toolkit of abuse, but its implementation is far reaching to the extent of blurring the line between what is right and what is wrong. The super majority of the cases studied in this research are the glaring testimonies for this verdict. It is self-evident that a widely written law is prone to abuse, however when such laws met an abusive, readymade criminal justice system and exclusionary and hostile political environment, the impact of such laws will be devastative. Ethiopia's anti-terrorism law and its implementation is a prototype of such abusive instances that ultimately signifies as quintessential case for how not to counter terrorism.

\section{Appendix}

(The complete list of court cases assessed in this study)

1. Abdi Kemal et al v The Federal Public Prosecutor (2 Individuals)

2. Abdiweli Mohamed and et al $v$ The Federal Public Prosecutor (4 Individuals)

3. Abdulaziz Jemalet al $v$ The Federal Public Prosecutor (5 Individuals)

4. Abdulkerim Abdusemed et al v The Federal Public Prosecutor (6 Individuals)

5. Abdulwahid Abdela et al v The Federal Public Prosecutor (20 Individuals)

6. Abdulwehab Mehadi et al v The Federal Public Prosecutor (8 Individuals)

7. Abebe Kassie et al v The Federal Public Prosecutor (5 Individuals)

8. Abebe Temesgen et al v The Federal Public Prosecutor (10 Individuals)

9. Abebe Urgessa et al v The Federal Public Prosecutor (6 Individuals)

10. Abebe Yehuala et al v The Federal Public Prosecutor (4 Individuals)

11. Abel Kebede et al $v$ The Federal Public Prosecutor (3 Individuals)

12. Abera Lema et al $v$ The Federal Public prosecutor (5 Individuals)

13. Abrham Zewdu et al v The Federal Public Prosecutor (5 Individuals)

14. Abubeker Ahmed et al $v$ The Federal Public Prosecutor (29 Individuals)

15. Adamu Taye et al $v$ The Federal Public Prosecutor (3 Individuals)

16. Ahmed Idris et al v The Federal Public Prosecutor (14 Individuals)

17. Ahmed Mustafa v The Federal Public Prosecutor

18. Alelachew Atalel et al v The Federal Public Prosecutor (5 Individuals)

19. Ali Adorus et al v The Federal Public Prosecutor (3 Individuals)

20. Aman Assefa et al v The Federal Public Prosecutor (27 Individuals)

21. Amanuel Desta v The Federal Public Prosecutor

22. Amin Yeyo et al $v$ The Federal Public Prosecutor (16 Individuals)

23. Amsalu Mestayet et al v The Federal Public Prosecutor (6 Individuals)

24. Andualem Arage et al v The Federal Public Prosecutor (24 Individuals)

25. Animut Tamo et al $v$ The Federal Public Prosecutor (3 Individuals)

26. Anteneh Tadesse v The Federal Public Prosecutor

27. Ashenafi Teshta et al $v$ The Federal Public Prosecutor (4 Individuals)

28. Asmarew Asseffa et al v The Federal Public Prosecutor (6 Individuals)

29. Assefa Gedamu et al v The Federal Public Prosecutor (2 Individuals)

30. Awol Abagida et al v The Federal Public Prosecutor (7 Individuals)

31. Ayanaw Tadesse et al v The Federal Public Prosecutor (2 Individuals)

32. Bachu Merega v The Federal Public Prosecutor 
33. Bati Muleta et al v The Federal Public Prosecutor (10 Individuals)

34. Bederu Ababor et al v The Federal Public Prosecutor (9 Individuals)

35. Bederi Yesuf et al v The Federal Public Prosecutor (5 Individuals)

36. Befekadu Abebe v The Federal Public Prosecutor

37. Birhanu Tekleyared et al v The Federal Public Prosecutor (4 Individuals)

38. Boset Bekele et al v The Federal Public Prosecutor (8 Individuals)

39. Chere Teklu et al v The Federal Public Prosecutor (3 Individuals)

40. Demeke Zewde v The Federal Public Prosecutor

41. Daniel Akuma et al v The Federal Public Prosecutor (2 Individuals)

42. Deko Wako et al v The Federal Public Prosecutor (2 Individuals)

43. Demissie Benti et al v The Federal Public Prosecutor (7 Individuals)

44. Dereje Alemu et al v The Federal Public Prosecutor (22 Individuals)

45. Desta Dinqa et al v The Federal Public Prosecutor (4 Individuals)

46. Dirbe Etana et al v The Federal Public Prosecutor (7 Individuals)

47. Diribsa Damete et al v The Federal Public Prosecutor (17 Individuals)

48. Elias Kediret al v The Federal Public Prosecutor (16 Individuals)

49. Elias Kifle et al v The Federal Public Prosecutor (5 Individuals)

50. Ethiopian Satellite Television and Oromia Media Network v The Federal Public Prosecutor

51. Feleke Gebrehiwot et al v The Federal Public Prosecutor (4 Individuals)

52. Fasika Getachew v The Federal Public Prosecutor

53. Fraol Daniel et al v The Federal Public Prosecutor (8 Individuals)

54. Gebremichael Gebreselassie et al v The Federal Public Prosecutor (9 Individuals)

55. Gebre Nigussie et al v The Federal Public Prosecutor (14 Individuals)

56. Getachew Shiferaw v The Federal Public Prosecutor

57. Girma Leul et al v The Federal Public Prosecutor (7 Individuals)

58. Gurmessa Ayano et al v The Federal Public Prosecutor (22 Individuals)

59. Habtamu Hachalu et al v The Federal Public Prosecutor (11 Individuals)

60. Habtamu Milkessa et al v The Federal Public Prosecutor (33 Individuals)

61. Hassan Abdunur et al v The Federal Public Prosecutor (5 Individuals)

62. HassenDawud v The Federal Public Prosecutor

63. Hassen Jarso et al v The Federal Public Prosecutor (11 Individuals)

64. Hindia Ibrahim et al v The Federal Public Prosecutor (2 Individuals)

65. Hussien Ali et al v The Federal Public Prosecutor (4 Individuals)

66. Hussien Tesso et al v The Federal Public Prosecutor (13 Individuals)

67. Ismael Bekele et al v The Federal Public Prosecutor (23 Individuals)

68. Jafar Mohamed et al v The Federal Public Prosecutor (7 Individuals)

69. Jeldesa Waqo et al v The Federal Public Prosecutor (3 Individuals)

70. Kassahun Shegie et al v The Federal Public Prosecutor (2 Individuals)

71. Kedir Mohamed et al v The Federal Public Prosecutor (19 Individuals)

72. Kedir Umer et al v The Federal Public Prosecutor (7 Individuals)

73. Kejela Gelana et al v The Federal Public Prosecutor (4 Individuals)

74. Kindu Mohammad et al v The Federal Public Prosecutor (9 Individuals)

75. Lemlemu Beshilew et al v The Federal Public Prosecutor (2 Individuals)

76. Ligabaw Girmaw v The Federal Public Prosecutor 
77. Lulu Mesele et al v The Federal Public Prosecutor (13 Individuals)

78. Masresha Sete et al v The Federal Public Prosecutor (38 Individuals)

79. Masresha Sete et al v The Federal Public Prosecutor II (7 Individuals)

80. Masresha Tafere et al v The Federal Public Prosecutor (10 Individuals)

81. Mebrate Yirga et al v The Federal Public Prosecutor (3 Individuals)

82. Mebratu Gebresilassie et al v The Federal Public Prosecutor (6 Individuals)

83. Mebrhatu Getahun et al v The Federal Public Prosecutor (5 Individuals)

84. Melkamu Ambachew et al v The Federal Public Prosecutor (3 Individuals)

85. Messay Teku et al v The Federal Public Prosecutor (2 Individuals)

86. Miftahshik Surur v et al v The Federal Public Prosecutor (77 Individuals)

87. Mistru Sissay et al v The Federal Public Prosecutor (4 Individuals)

88. Getachew Mekonnen et al v The Federal Public Prosecutor (16 Individuals)

89. Mamuye Diro v The Federal Public Prosecutor

90. Mohammad Abdulkadir v The Federal Public Prosecutor

91. Mohammad Abdurahman et al v The Federal Public Prosecutor (8 Individuals)

92. Mohammad Agonafir et al v The Federal Public Prosecutor (2 Individuals)

93. Mohammad Ali et al v The Federal Public Prosecutor (2 Individuals)

94. Mohammad Ame et al v The Federal Public Prosecutor (5 Individuals)

95. Negede Shwakena et al v The Federal Public Prosecutor (2 Individuals)

96. Nigest Yirga et al v The Federal Public Prosecutor (6 Individuals)

97. Okelo Akuwai et al v The Federal Public Prosecutor (7 Individuals)

98. Olana Kebede et al v The Federal Public Prosecutor (21 Individuals)

99. Omod Uket et al v The Federal Public Prosecutor (12 Individuals)

100. Omot Aguwa et al v The Federal Public Prosecutor (3 Individuals)

101. Piliman Kuwot et al v The Federal Public Prosecutor (10 Individuals)

102. Riseku Alemu et al v The Federal Public Prosecutor (5 Individuals)

103. Soliana Shimeles et al v The Federal Public Prosecutor (10 Individuals)

104. Tadesse Ferede et al v The Federal Public Prosecutor (5 Individuals)

105. Tadesse Mesele et al v The Federal Public Prosecutor (4 Individuals)

106. Tariku Belay et al v The Federal Public Prosecutor (2 Individuals)

107. Tefera Belay et al v The Federal Public Prosecutor (10 Individuals)

108. Terefe Yitayeh et al v The Federal Public Prosecutor (4 Individuals)

109. Tesfaye Gutu et al v The Federal Public Prosecutor (7 Individuals)

110. Tesfaye Kiros v Tigray Regional State Public Prosecutor

111. Teshome Ragassa et al v The Federal Public Prosecutor (16 Individuals)

112. Tilahu Edosa et al v The Federal Public Prosecutor (4 Individuals)

113. Tinsaie Beriso et al v The Federal Public Prosecutor (10 Individuals)

114. Tolosa Beyene et al v The Federal Public Prosecutor (3 Individuals)

115. Tsegaw Alemu et al v The Federal Public Prosecutor (5 Individuals)

116. Uchumi Apey et al v The Federal Public Prosecutor (10 Individuals)

117. Worku Ferede et al v The Federal Public Prosecutor (5 Individuals)

118. Yohannes Mengiste et al v The Federal Public Prosecutor (6 Individuals)

119. Yonatan Tesfaye v The Federal Public Prosecutor

120. Zelalem Workagegnehu et al v The Federal Public Prosecutor (10 Individuals)

121. Zemen Kasse et al v The Federal Public Prosecutor (9 Individuals)

122. Zemene Miheret et al v The Federal Public Prosecutor (3 Individuals) 
123. Ziyad Shafi et al v The Federal Public Prosecutor (2 Individuals) 